\title{
Managerial Ability, Tone of Earnings Announcements, and Market Reaction
}

\begin{abstract}
Purpose - This study examines the effect of managerial ability on the tone of earnings announcements and on the market response to the tone.

Design/methodology/approach - This study constructs a model of the determinants of earnings announcement tone in order to examine whether managerial ability plays a significant role in determining earnings announcement tone. Further, to test whether the market response to the tone of earnings announcements is affected by managerial ability, this study also examines the interactive term between earnings announcement tone and managerial ability. The tone of earnings announcements is measured using the spread in the proportion of positive and negative words. Managerial ability is measured using the managerial ability rank developed by Demerjian et al. (2012).

Findings - More able management teams use a more positive tone in their earnings announcements. Stock markets have more pronounced positive reactions to positive tones in the earnings announcements issued by companies with more able management teams.

Originality/value - This study identifies managerial ability as a previously unrecognized determinant of tone in earnings announcements and of the stock price reaction to earnings announcements.
\end{abstract}

Keywords Earnings Announcement, Managerial Ability, Market Reaction, Tone Paper Type Research Paper 


\section{Managerial Ability, Tone of Earnings Announcements, and Market Reaction}

\section{Introduction}

To what extent does management team ability affect the language used in a firm's earnings announcement? Perhaps the most commonly studied feature of corporate communication is the spread in the proportion of positive and negative words - often referred to as "tone" (e.g., Frankel et al., 2010; Price et al., 2012; Davis and Tama-Sweet, 2012; Davis et al., 2012; Demers and Vega, 2014; Huang et al., 2014; Arslan-Ayaydin et al., 2016). Prior studies have found that the tone of corporate disclosure is related to both current firm profitability and to management incentives. This study explores an alternative determinant of tone, i.e., managerial ability, which is defined as a management team's efficiency, relative to its industry peers, in transforming corporate resources into revenues (Demerjian et al., 2012).

The study also examines how managerial ability influences the market response to the tone of earnings announcements. Earnings announcements have been characterized as the most visible and timely channel for managers to communicate quarterly operational performance and are known to contain contents that affect stock returns (Davis and Tama-Sweet, 2012; Chen et al., 2015), and have been described in the Financial Times as "the most prized communication between the companies and investors" (Jopson, 2007). Prior research shows that the tone of earnings announcements not only signals managers' expectations regarding economic performance, but that the market reacts positively to a positive tone in the short window around an earnings announcements date (Henry, 2008; Davis et al., 2012; Davis and Tama-Sweet, 2012).

This study is informed by three lines of research. First, Demerjian et al. $(2012,2013)$ and Krishnan and Wang (2015) document that managerial ability impacts operational outcomes, firm value, earnings quality, audit risk, and auditors' reporting decision. Second, Davis et al. (2015) 
document that individual manager-specific characteristics play a significant role in the language used in voluntary disclosures (e.g., earnings announcement-related conference calls). Third, Davis et al. (2012) and Henry (2008) suggest that stock markets price tone into their valuations at the time of an earnings announcement. Therefore, this study posits that managerial ability impacts the tone of earnings announcements and that the market is in fact reacting to managerial ability when it reacts to the tone in earnings announcements.

In this study, managerial ability is measured using the managerial ability rank $\left(M A_{-} R\right.$ hereafter) developed by Demerjian et al. (2012). The analysis of a sample of 15,885 quarterly earnings announcement releases from the 1994Q1 to 2011Q4 period shows that firms with higher managerial ability adopt a more positive tone in their earnings announcements, and that the market has a stronger response to a positive tone in the earnings announcements issued by firms with stronger management teams. Overall, these findings suggest that managerial ability is an important determinant of tone that complements other documented determinants of tone, such as operational performance, managerial incentives, growth opportunities, and firm size. The implication is that a superior management team is more knowledgeable about its business (e.g., the firm, the industry, the client base, and the macro-economic condition), is more able to achieve a better operational outcome, and is likely to create more positive expectations of its firm's operational performance, resulting in a more positive tone in earnings announcements. ${ }^{1}$ This insight is helpful for interpreting market reactions to the tone of earnings announcements. Specifically, the stronger positive response to a positive tone in the earnings announcements of strong management teams suggests that investors are capable of effectively incorporating the qualitative information signal conveyed in the tone of the earnings announcements. 
This study contributes to the literature in two ways. First, the tone of earnings announcements has been the subject of growing scholarly interest. This study contributes to this literature by not only identifying a new determinant of tone, i.e., management team ability, but also by showing that managerial ability helps to explain the price reaction around earnings announcements. This study's findings on the impact of management teams on the tone of earnings announcements supplement the recent findings by Davis et al. (2015), who suggest that individual manager-specific tendencies to be optimistic influence the tone of voluntary disclosures (e.g. conference calls); this study extends this insight by suggesting that a management team's ability as a group impacts the tone of voluntary disclosures (e.g., management earnings announcement). Furthermore, the study provides evidence that managerial ability not only enhances the earnings quality in GAAP accounting numbers in regulated, mandatory financial statements (Demerjian et al., 2013) and audit quality (Krishnan and Wang, 2015), it also increases the impact of the qualitative information provided in voluntary disclosures, specifically, the tone of earnings announcements.

The remainder of the paper is organized as follows. Section II discusses the related literature and hypotheses development. Section III explains the sample selection process, measurements of key variables, and descriptive statistics. Section IV presents the empirical models and main results. Section V provides additional analysis. Part VI discusses some robustness checks. Part VII concludes the paper.

\section{Hypotheses development}

A number of studies have examined the determinants of and market reactions to the tone of different types of corporate disclosure. Davis et al. (2012) and Demers and Vega (2014) examine tone in earnings announcements and find that (1) tone is related to corporate performance 
and (2) the market reacts positively to the tone expressed in earnings announcements. These studies generally interpret their results as consistent with the notion that managers use tone to communicate private information about the performance of the firm. This study examines the effect of management-team ability on the tone of earnings announcements and its impact on the market reaction to the tone at the time of the earnings announcement.

\subsection{Managerial ability and tone of earnings announcements}

Prior studies have identified manager-specific effects on a firm's performance, investment and financing decisions (Bertrand and Schoar, 2003), accounting choices (Ge et al., 2011), forecast choices (Bamber et al., 2010; Yang, 2012), and tax aggressiveness (Dyreng et al., 2010). Davis et al. (2015) explicitly point out that individual managers impact a firm's financial reporting and disclosure choices beyond the economic factors that are specific to the firm, even though many of these reporting decisions are constrained by factors such as Generally Accepted Accounting Principles, external auditors, and regulators. Given the unstructured and unregulated nature of the choice of language in voluntary disclosures, the tone of such disclosures (e.g., earnings announcements and conference calls) is likely to be more influenced by manager-specific characteristics (Hambrick, 2007; Davis and Tama-Sweet, 2012; Davis et al., 2015). Davis et al. (2015) test this proposition and find that an individual manager's tendency to be optimistic influences the tone of conference calls as well as a firm's operational performance. This study extends Davis et al. (2015) by examining how a management team's ability affects the tone used in its earnings announcements.

Demerjian et al. (2012) define managerial ability as a management team's efficiency, relative to its industry peers, in transforming corporate resources into revenues. Demerjian et al. argue that more able managers are better than less able managers at understanding technological 
and industrial trends, predicting product demand, investing in higher value projects, managing their employees, and successfully identifying and capitalizing on investment opportunities. The superior knowledge and efficiency of more able management teams helps their firms to achieve better operational performance (Demerjian et al., 2012) and to provide the market with higher quality financial reporting information (Demerjian et al., 2013; Krishnan and Wang, 2015)[2].

Given the above, the prediction is that there is a management team-specific component to the tone of earnings announcements. In particular, managerial ability might have a significant effect on the language used in earnings announcements through at least two channels: management private information and management optimism. First, according to the argument in Demerjian et al. (2013), a superior management team is more knowledgeable about its business (e.g., the firm, the industry, the client base, and the macro-economic condition), and is more able to achieve a better operational outcome. Thus, a superior management team is likely to create more positive expectations of its firm's operational performance, which should result in a more positive tone in their earnings announcement. Second, managerial ability is associated with management's confidence and optimism (Gul, 1983), which also result in more optimistic accounting numbers (Ahmed and Duellman, 2013) and more optimistic tones in conference calls (Davis et al., 2015). Both arguments suggest that managerial ability is likely to be positively associated with the tone of earnings announcement. Stated in alternative form, the first hypothesis is as follows:

Hypothesis 1. Ceteris paribus, a more able management team is likely to issue an earnings announcement with a more positive tone.

The null of Hypothesis 1 (H1) might occur for three reasons. First, the potential litigation risk and reputational costs associated with overly positive language are two major factors constraining more able management teams from issuing more positive earnings announcements (e.g., Rogers et al., 2011; Gordon et al., 2013; Arslan-Ayaydin et al., 2016; Davis et al., 2015). 
Second, each earnings announcement is carefully scrutinized by the board and its audit committee before being released (Deloitte, 2015), limiting the impact of a management team on its tone. Third, it is possible that the majority of the variation in the tone of earnings announcements is driven by innate firm characteristics that managers cannot affect; in this case, there will not be any association between management team ability and the tone of earnings announcements

\subsection{Relevance of managerial ability to understanding the market reaction to the tone of earnings} announcements

Earnings announcements have been characterized as the most visible and timely channel for managers to communicate quarterly operational performance (Davis and Tama-Sweet, 2012). There exists strong evidence that the market uses qualitative information from earnings announcements to infer managers' private information about firms' prospects and value. For example, Henry (2008), Davis et al. (2012), Price et al. (2012), and Demers and Vega (2014) document the immediate effect of the tone of earnings announcements on investors' perceptions of a firm's operational performance. They show that the 3-day cumulative abnormal return around an earnings announcement increases with the positive tone of the earnings announcement, even after controlling for a firm's financial information and earnings surprise. These early studies (e.g., Henry, 2008; Davis et al., 2012) of the qualitative information in earnings press releases mainly interpret tone as an unbiased signal of a manager's private information about corporate performance. However, Huang et al. (2014) provide evidence that managers can, at their discretion, use optimistic language (tone) in earnings announcements to hype a stock before important events, including equity offerings, mergers and acquisitions, and stock options grants. Similarly, Arslan-Ayaydin et al. (2016) find that equity incentives increase the likelihood that managers will inflate the tone of earnings announcements, but that as investors anticipate the 
opportunistic behavior of managers with large equity incentives, they discount the (inflated) tone in their valuation of such firms' stock.

Recent studies by Price et al. (2012) and Davis et al. (2015) find evidence of a managerspecific component in the market reaction to the tone of conference calls, which is consistent with the notion that manager-specific optimism impacts investors' interpretation of voluntary disclosures (e.g., conference calls). This study complements this line of research by examining the impact of management teams' ability on the market response to tone. This study posits that managerial ability is relevant to investors' valuation of a firm's stock in the short window around an earnings announcement. Furthermore, as opportunistic tone management is anticipated by investors (Huang et al., 2014; Arslan-Ayaydin et al., 2016), this study posits that investors are also likely to take managerial ability into account by increasing (decreasing) the influence of the tone on firm valuation for firms with more (less) able management teams. Stated in alternative form, the second hypothesis is as follows:

Hypothesis 2. Ceteris paribus, the market reacts more positively to a positive tone in an earnings announcement issued by a company with a more able management team.

The null of Hypothesis 2 (H2) might occur for two reasons. First, previous findings show an immediate positive stock market reaction to positivism in earnings announcements (e.g., Henry, 2008; Davis et al., 2012; Davis and Tama-Sweet, 2012). This empirical evidence suggests that market participants consider an optimistic tone in earnings announcement as, to some extent, an unbiased positive signal about a company's economic conditions (Henry, 2008; Davis et al., 2012). If this belief in an unbiased signal dominates, the market will not respond differently to the tone of earnings announcements issued by more or less able management teams. Second, if market participants are not able to differentiate companies with better or worse managerial teams, the 
market will not react differently to earnings announcements issued by management teams with different abilities.

\section{Sample selection, variable definitions, and descriptive statistics}

\subsection{Sample selection}

The sample dataset used in the analysis of the positivity and negativity of tones in earnings announcements consists of data drawn from WRDS SEC Analytics Suite, managerial ability data developed in Demerjian et al. (2012), annual financial data from Compustat, data on executive wealth from ExecuComp, stock return data from the Center for Research in Security Prices (CRSP), and analyst forecast data from Thomson Reuters I/B/E/S. Any observation with missing data is dropped. Observations from regulated industries such as electricity, gas, finance, insurance, and real estate are dropped. The final sample includes 15,885 firm-quarter observations from the 1994Q1 to $2011 \mathrm{Q} 4$ period. All of the data are winsorized at $1 \%$ and $99 \%$. Table 1 describes the sample selection procedure.

Table 1. Sample selection

\begin{tabular}{lcl}
\hline \hline & Firms & $\begin{array}{l}\text { Firm-quarter } \\
\text { observations }\end{array}$ \\
\hline Non-missing data from Compustat and SEC Analytics Suite & 6,504 & 69,232 \\
Merge with ExecuComp & 2,149 & 32,565 \\
Merge with managerial ability data & 1,676 & 25,202 \\
Merge with CRSP daily data & 993 & 17,807 \\
Merge with I/B/E/S & 919 & 16,064 \\
Remove regulated industries & 912 & 15,956 \\
Merge with CRSP monthly data & 909 & 15,885 \\
\hline \hline
\end{tabular}




\subsection{Tone of earnings announcement}

Consistent with prior studies (Feldman et al., 2010; Davis and Tama-Sweet, 2012; Twedt and Rees, 2012; Davis et al., 2015), TONE is measured as the difference between the number of positive words and the number of negative words divided by the total number of words in the earnings announcement. All of the earnings announcements are retrieved from WRDS SEC Analytics Suite. The number of positive and negative words is pre-calculated using the dictionary developed in Loughran and McDonald (2011). Specifically, Loughran and McDonald (2011) parse the texts of $10-\mathrm{Ks}$ and $10-\mathrm{K} 405 \mathrm{~s}$ into vectors of words and word counts, and calculate the tone of the 10-Ks based on word counts, the positivity and negativity of each word, frequency of each word, and importance of each word. They demonstrate that tone calculated in this way is associated with market abnormal returns, trading volumes, return volatility, and earnings surprises. Their library of positive and negative words has been used by a number of studies such as Twedt and Rees (2012), Garcia (2013), Jegadeesh and Wu (2013), Liu and McConnell (2013), and Loughran and McDonald (2014). In this study, consistent with Huang et al. (2014) and Arslan-Ayaydin et al. (2016), the abnormal tone, ABTONE, is also calculated, as shown in equation (3). Additional analyses using $A B T O N E$ are presented in Section V.

\subsection{Managerial ability measure [3]}

Demerjian et al. (2012) define managerial ability as the ability of managers, relative to their industry peers, to maximize revenues and profitability. The managerial ability ranking method developed by Demerjian et al. produces decile rankings of managerial ability scores. In particular, using data envelopment analysis (DEA), a nonlinear optimization procedure used to evaluate the relative efficiency of decision-making units, they estimate firm efficiency by solving 
an optimization model in which sales is the output and there are seven inputs: net property, plant and equipment; net operating leases; net R\&D; purchased goodwill; other tangible assets; cost of inventory; and selling, general, and administrative expenses. The objective is to identify firms that generate the highest level of revenue from a given set of inputs. The second step involves estimating managerial ability from the firm efficiency measure. As the latter reflects both firmlevel and manager-specific efficiency drivers, Demerjian et al. (2012) separate the two by estimating for each industry a regression of firm efficiency on six firm characteristics that affect firm efficiency: firm size, firm market share, cash availability, firm age, business segment concentration, and foreign operations. The residual from this regression is the managerial ability score. It indicates managers' ability, relative to their industry peers, to transform corporate resources to revenues. This study uses the managerial ability rankings published by Demerjian et $a l$. as a measure of managerial ability $\left(M A_{-} R\right)[4]$.

\subsection{Other variables}

The cumulative abnormal return is calculated as the difference between the holding period return and the CRSP value-weighted market index return surrounding an event window. As this study is focused on earnings announcements and reactions to earnings announcements, the day of an earnings announcement is day 0 ; in the calculation of $C A R(-1,1)$, day -1 is the day before an announcement, and day 1 is the day after. $C A R(-60,-2)$ is a control variable, with day -60 being 60 days before an earnings announcement, and day -2 being 2 days before.

The other control variables include return on assets (ROA), firm size (SIZE), market-tobook ratio $(M T B)$, stock return volatility $(V O L)$, CEO equity-based wealth (WEALTH), earnings surprise (SURP), and year, quarter, and industry fixed effects. $R O A$, calculated as earnings before 
interest and taxes scaled by total assets, captures firm fundamentals. According to prior studies (e.g., Davis and Tama-Sweet, 2012; Davis et al., 2015), it is necessary to control for ROA, as it is likely to affect the tone in earnings announcements. Further, larger firms are likely to use a different tone than smaller firms, as documented in Jegadeesh and Wu (2013) and Huang et al. (2014), and hence this study controls for firm size (SIZE), measured as the logarithm of total assets. A number of studies on tone (e.g., Jegadeesh and Wu, 2013; Huang et al., 2014; Davis et al., 2015) suggest that it is also necessary to control for a firm's growth potential, which can be proxied by market-to-book ratio (MTB). VOL is calculated as the standard deviation of monthly stock return in the past 12 months, proxy for firm-specific risk (Huang et al. 2014). Arslan-Ayaydin et al. (2016) document that the tone of earnings announcements is impacted by CEO equity-based incentives, and therefore this study also controls for CEO equity-based wealth (WEALTH), calculated as the logarithm of the aggregate dollar amount of a CEO's firm-specific equity-based wealth, which includes the total value of shares owned by the CEO, value of unexercisable options, and value of unexercised exercisable options. Earnings surprise (SURP) is calculated as the difference between the mean analyst forecast of EPS and the actual EPS.

\subsection{Descriptive statistics}

Table 2 reports the descriptive statistics of the test variables and control variables. An average firm has a tone of 0.180 , suggesting that earnings announcements generally have a positive tone. This observation is consistent with the findings of Davis and Tama-Sweet (2012) and Davis et al. (2015), who document positive average tones in earnings announcements. Table 2 also shows that, on average, the sample firms have a positive $R O A$. The mean of CEO's firm-specific equitybased wealth is about $\$ 80$ million, while the median is a little over $\$ 14$ million. After a logarithm 
transformation is performed to address the right-skewness of the data, WEALTH is found to have a mean of 9.447 and a median of 9.550 . Finally, both the average $C A R(-1,1)$ and the average $C A R(-$ $60,-2)$ are positive.

Table 2. Descriptive statistics

\begin{tabular}{lccccccc}
\hline \hline Variables & \# of ob. & Mean & Min. & $25 \%$ & Median & $75 \%$ & Max. \\
\hline TONE & 15,885 & 0.180 & -1.739 & 0.000 & 0.329 & 0.420 & 1.195 \\
ABTONE & 15,885 & 0.028 & -1.880 & -0.154 & 0.172 & 0.270 & 1.040 \\
MA_R & 15,885 & 0.581 & 0.1 & 0.4 & 0.6 & 0.8 & 1.0 \\
WEALTH & 15,885 & 9.450 & 0.000 & 8.504 & 9.549 & 10.571 & 14.017 \\
ROA & 15,885 & 0.032 & -0.263 & 0.010 & 0.030 & 0.060 & 0.209 \\
SIZE & 15,885 & 7.557 & 4.350 & 6.395 & 7.407 & 8.644 & 12.012 \\
MTB & 15,885 & 1.258 & 0.143 & 0.530 & 0.810 & 1.420 & 8.345 \\
VOL & 15,885 & 0.120 & 0.043 & 0.083 & 0.107 & 0.150 & 0.319 \\
SURP & 15,885 & -0.018 & -1.182 & -0.054 & 0.003 & 0.048 & 0.594 \\
CAR(-1,1) & 15,885 & 0.004 & -0.230 & -0.038 & 0.003 & 0.047 & 0.231 \\
CAR(-60,-2) & 15,885 & -0.005 & -0.513 & -0.099 & -0.005 & 0.089 & 0.531 \\
\hline \hline
\end{tabular}

\subsection{Correlations}

The Pearson correlations are presented in Table 3. They show a positive and significant correlation between $T O N E$ and $M A \_R$. TONE is also positively associated with CEO equity-based incentives (proxied by WEALTH), firm fundamentals (proxied by $R O A$ ), and growth potential (proxied by $M T B$ ). However, TONE is negatively associated with $S I Z E$ and $V O L$, suggesting that larger, risky firms might be more cautious in earnings announcements. In addition, TONE is positively associated with $C A R(-1,1)$, indicating that a more positive tone may be associated with a more positive market reaction.

Additionally, $M A_{-} R$ is positively associated with $W E A L T H, R O A, M T B$, and $C A R(-1,1)$. This is in line with the notion that $M A_{-} R$ captures managers' relative efficiency in transforming corporate resources into revenues. In particular, higher managerial ability is correlated with higher firm fundamentals (proxied by $R O A$ ), higher growth (proxied by $M T B$ ), higher CEO equity-based 
incentive (proxied by WEALTH), and a stronger market reaction to earnings announcements (proxied by $C A R(-1,1)$ ). 
Table 3. Pearson correlations

\begin{tabular}{|c|c|c|c|c|c|c|c|c|c|c|c|}
\hline & TONE & ABTONE & $M A \_R$ & WEALTH & $R O A$ & SIZE & $M T B$ & $V O L$ & $S U R P$ & $C A R(-1,1)$ & $C A R(-60,-2)$ \\
\hline TONE & 1.000 & $0.998 * * *$ & $0.039 * * *$ & $0.015 *$ & $0.077 * * *$ & $-0.037 * * *$ & $0.027 * * *$ & $-0.071 * * *$ & $0.041 * * *$ & $0.018 * *$ & -0.007 \\
\hline ABTONE & & 1.000 & $0.025 * * *$ & $-0.021 * * *$ & $0.050 * * *$ & 0.002 & 0.011 & $-0.084 * * *$ & $0.031 * * *$ & $0.015 *$ & -0.005 \\
\hline$M A \_R$ & & & 1.000 & $0.121 * * *$ & $0.282 * * *$ & $-0.056 * * *$ & $0.241 * * *$ & -0.010 & $0.145^{* * *}$ & 0.011 & $-0.036 * * *$ \\
\hline WEALTH & & & & 1.000 & $0.223 * * *$ & $0.324 * * *$ & $0.104 * * *$ & $-0.153 * * *$ & $0.127 * * *$ & $0.027 * * *$ & -0.013 \\
\hline$R O A$ & & & & & 1.000 & $0.080 * * *$ & $0.193 * * *$ & $-0.201 * * *$ & $0.266 * * *$ & $0.023 * * *$ & $-0.095 * * *$ \\
\hline SIZE & & & & & & 1.000 & $-0.208 * * *$ & $-0.441 * * *$ & 0.011 & $-0.022 * * *$ & -0.009 \\
\hline MTB & & & & & & & 1.000 & $0.332 * * *$ & $0.086^{* * *}$ & $-0.040 * * *$ & $-0.066 * * *$ \\
\hline$V O L$ & & & & & & & & 1.000 & -0.007 & -0.013 & $-0.036^{* * *}$ \\
\hline$S U R P$ & & & & & & & & & 1.000 & $0.153 * * *$ & $-0.037 * * *$ \\
\hline$C A R(-1,1)$ & & & & & & & & & & 1.000 & 0.008 \\
\hline$C A R(-60,-2)$ & & & & & & & & & & & 1.000 \\
\hline
\end{tabular}

*,**, and *** indicate significance at a $10 \%, 5 \%$, and $1 \%$ level, respectively. 


\section{Empirical models and main results}

\subsection{Empirical models}

The following fixed effects regression, in which industry, year, and quarter fixed effects are controlled, is used to test the first hypothesis.

$$
\begin{gathered}
\text { TONE } E_{i t}=\alpha_{1} M_{-} R_{i t}+\alpha_{2} \text { WEALTH }_{i t}+\alpha_{3} R O A_{i t}+\alpha_{4} \text { SIZE }_{i t}+\alpha_{5} \text { MTB }_{i t}+\alpha_{6} \text { VOL }_{i t} \\
+\Sigma I N D+\Sigma Y E A R+\Sigma Q U A R T E R+\varepsilon_{i t}
\end{gathered}
$$

Consistent with previous studies on tone (e.g., Davis and Tama-Sweet, 2012; Jegadeesh and Wu, 2013; Huang et al., 2014; Arslan-Ayaydin et al., 2016), model (1) controls for CEO equity-based incentive, performance, size, growth potential, and stock return volatility. According to Jegadeesh and Wu (2013), Huang et al. (2014), and Arslan-Ayaydin et al. (2016), smaller firms as well as firms with higher CEO equity-based wealth, larger market-to-book ratios, lower stock return volatility, and higher return on assets are likely to use more positive tones in their earnings announcements. The variable of interest is $M A \_R$, with $\alpha_{1}$ representing the association between tone and managerial ability. The first hypothesis states that more able management teams are likely to issue earnings announcements with more positive tones; therefore, the testable hypothesis for $\mathrm{H} 1$ is that $\alpha_{1}$ is positive and significant.

To test the second hypothesis the following fixed effects regression is performed.

$$
\begin{aligned}
C A R(-1,1)_{i t} & =\beta_{1} T_{O N E_{i t}}+\beta_{2} M A_{-} R_{i t}+\beta_{3} T O N E_{i t} * M A_{R_{i t}}+\beta_{4} C A R(-60,-2)_{i t} \\
& +\beta_{5} S U R P_{i t}+\beta_{6} R O A_{i t}+\beta_{7} S I Z E_{i t}+\beta_{8} M T B_{i t}+\beta_{9} V O L_{i t}+\Sigma I N D \\
& +\Sigma Y E A R+\Sigma Q U A R T E R+\varepsilon_{i t}
\end{aligned}
$$

A number of studies have shown that the stock market reacts positively to the tone of earnings announcements (e.g., Feldman et al., 2010; Davis and Tama-Sweet, 2012; Twedt and Rees, 2012; Price et al., 2012). Building on this literature, model (2) tests whether managerial ability affects the market reaction to earnings announcement tones. $C A R(-1,1)$ is the 3-day cumulative abnormal return around day 0 , i.e., the earnings announcement release day. The control 
variables are $C A R(-60,-2), S U R P, R O A, S I Z E, M T B$, and the fixed effects on industry, year, and quarter. $C A R(-60,-2)$ is used to capture any possible delayed market reaction to prior events. A positive and significant association between positive market reaction and positive tones is expected. Also, firms with positive earnings surprises, higher earnings, smaller sizes, and lower growth are expected to have higher cumulative abnormal returns (Pinello, 2008; Doran et al., 2012; Davis and Tama-Sweet, 2012; Huang et al., 2014; Davis et al., 2015; Arslan-Ayaydin et al., 2016). Industry, year, and quarter fixed effects are included, as industry-wide and macro economy fluctuations might affect market reactions. The second hypothesis states that the market reacts more positively to a positive tone in an earnings announcement issued by a company with a more able management team. Hence, to support $\mathrm{H} 2, \beta_{3}$ must be positive and significant.

\subsection{Main results}

Table 4 reports the empirical results for the first hypothesis. The results of the regression of earnings announcement tone against managerial ability rank $\left(M A_{-} R\right)$ show that TONE is positively associated with $M A_{-} R$, with a coefficient of 0.040 and a significance level of $1 \%$. This suggests that a more able management team is likely to exhibit a more positive tone in its earnings announcements [5]. The empirical results for the control variables are consistent with prior studies (e.g., Doran et al., 2012; Huang et al., 2014; Davis et al., 2015; Arslan-Ayaydin et al., 2016). In particular, CEO equity-based wealth and ROA are significantly and positively associated with a more positive tone, suggesting that firms with higher CEO equity-based wealth and better operational performance are likely to adopt a more positive tone in their earnings announcements. Consistent with Huang et al. (2014), SIZE is negatively associated with TONE, suggesting that larger firms may use more cautious (more negative) tones in their earnings announcements. 
Overall, the results support the hypothesis that higher managerial ability is associated with a more positive tone in earnings announcements.

Table 4. OLS regression of earnings announcement tones

\begin{tabular}{|c|c|}
\hline & TONE \\
\hline$M A \_R$ & $\begin{array}{c}0.039 * * * \\
(2.83)\end{array}$ \\
\hline WEALTH & $\begin{array}{c}0.007 * * * \\
(3.63)\end{array}$ \\
\hline$R O A$ & $\begin{array}{c}0.398^{* * *} \\
(6.45)\end{array}$ \\
\hline SIZE & $\begin{array}{c}-0.008 * * * \\
(-3.27)\end{array}$ \\
\hline$M T B$ & $\begin{array}{c}0.0009 \\
(0.31)\end{array}$ \\
\hline$V O L$ & $\begin{array}{l}-0.126 \\
(-1.42)\end{array}$ \\
\hline $\begin{array}{l}\text { Industry Fixed Effect } \\
\text { Year Fixed Effect } \\
\text { Quarter Fixed Effect }\end{array}$ & $\begin{array}{l}\text { Included } \\
\text { Included } \\
\text { Included }\end{array}$ \\
\hline $\begin{array}{c}R^{2} \\
\# O b s .\end{array}$ & $\begin{array}{l}0.0931 \\
15,885\end{array}$ \\
\hline
\end{tabular}

$*, * *$, and $* * *$ indicate significance at a $10 \%, 5 \%$, and $1 \%$ level, respectively. T-statistics are in parentheses. The above table presents the results from the following regression:

TONE $E_{i t}=\alpha_{1} M A_{-} R_{i t}+\alpha_{2}$ WEALTH $_{i t}+\alpha_{3}$ ROA $_{i t}+\alpha_{4}$ SIZE $_{i t}+\alpha_{5} M T B_{i t}+\alpha_{6} V O L_{i t}+\Sigma I N D+\Sigma Y E A R$ $+\Sigma Q U A R T E R+\varepsilon_{i t}$

TONE is measured as 100 multiplied by the difference between the positive word proportion and negative word proportion. $M A \_R$ is obtained at http://faculty.washington.edu/smcvay/abilitydata.html. WEALTH is the logarithm of the sum of three components: (1) aggregate value of shares owned by the CEO, (2) aggregate value of unexercisable options, and (3) aggregate value of unexercised exercisable options. $R O A$ is earnings before interest and taxes (EBIT) scaled by total assets. SIZE is calculated as the logarithm of (1+total assets), market-to-book ratio $(M T B)$ is the sum of market capitalization and long-term debt divided by total assets, and stock return volatility $(V O L)$ is the volatility of monthly stock returns in the past 12 months. 
Table 5 presents the empirical findings for H2. The results presented in column (1) show the result for the base model: there is a positive market reaction to positive tones, with a coefficient of 0.002 that is marginally significant at the $12 \%$ level. Column (2) of Table 5 , which presents the regression results for $M A_{-} R$ and the interaction between TONE and $M A_{-} R$, shows that the interaction term is positively associated with cumulative abnormal returns, with a coefficient of 0.012 , and a t-value of 2.24. This suggests that when the market reacts to the tone of earnings announcements, it also considers managerial ability. If the management team is more able, the market's abnormal reaction is higher. Further, to test the overall association between $C A R(-1,1)$ and TONE, this study examines whether $\beta_{1}+\beta_{3}$ equals zero. The parameter is 0.007 and is significantly different from zero at the $1 \%$ level, indicating that $C A R(-1,1)$ is indeed associated with the tone of earnings announcements. The results for the control variables in both columns are consistent with prior studies. Specifically, larger firms (higher SIZE) and more rapid growth (higher $M T B$ ) are likely to have smaller abnormal reactions, consistent with the evidence in Huang et al. (2014), Davis et al. (2015), and Arslan-Ayaydin et al. (2016). Also, a bigger earnings surprise $(S U R P)$ is associated with a higher abnormal return, whereas $R O A$ is not significantly associated with a higher abnormal return. This suggests that the market reacts to discrepancies between analyst forecasts and real earnings $(S U R P)$, but not directly to earnings $(R O A)$. 
Table 5. OLS regression of market reaction

\begin{tabular}{|c|c|c|}
\hline & $\begin{array}{c}(1) \\
\text { CAR }(-1,1)\end{array}$ & $\begin{array}{c}(2) \\
C A R(-1,1)\end{array}$ \\
\hline TONE & $\begin{array}{l}0.002 \\
(1.57)\end{array}$ & $\begin{array}{l}-0.005 \\
(-1.35)\end{array}$ \\
\hline$M A \_R$ & & $\begin{array}{l}0.001 \\
(0.45)\end{array}$ \\
\hline$T O N E * M A \_R$ & & $\begin{array}{c}0.012 * * \\
(2.24)\end{array}$ \\
\hline$C A R(-60,-2)$ & $\begin{array}{l}0.003 \\
(0.82)\end{array}$ & $\begin{array}{l}0.003 \\
(0.80)\end{array}$ \\
\hline$S U R P$ & $\begin{array}{c}0.065^{* * *} \\
(20.48)\end{array}$ & $\begin{array}{c}0.065^{* * *} \\
(20.40)\end{array}$ \\
\hline$R O A$ & $\begin{array}{c}-0.00008 \\
(-0.07)\end{array}$ & $\begin{array}{l}-0.004 \\
(-0.31)\end{array}$ \\
\hline SIZE & $\begin{array}{c}-0.002 * * * \\
(-3.61)\end{array}$ & $\begin{array}{c}-0.002 * * * \\
(-3.50)\end{array}$ \\
\hline$M T B$ & $\begin{array}{c}-0.004 * * \\
(-7.06)\end{array}$ & $\begin{array}{c}-0.004^{* *} \\
(-7.19)\end{array}$ \\
\hline$V O L$ & $\begin{array}{l}-0.011 \\
(-0.70)\end{array}$ & $\begin{array}{l}-0.011 \\
(-0.67)\end{array}$ \\
\hline $\begin{array}{l}\text { Industry Fixed Effect } \\
\text { Year Fixed Effect } \\
\text { Quarter Fixed Effect }\end{array}$ & $\begin{array}{l}\text { Included } \\
\text { Included } \\
\text { Included }\end{array}$ & $\begin{array}{l}\text { Included } \\
\text { Included } \\
\text { Included }\end{array}$ \\
\hline F-test: $\beta_{1}+\beta_{3}=0$ & & $\begin{array}{c}0.007 * * * \\
(2.72) \\
\end{array}$ \\
\hline $\begin{array}{c}R^{2} \\
\# O b s .\end{array}$ & $\begin{array}{l}0.0355 \\
15,885 \\
\end{array}$ & $\begin{array}{l}0.0359 \\
15,885 \\
\end{array}$ \\
\hline
\end{tabular}

$*, * *$, and $* * *$ indicates significance at a $10 \%, 5 \%$, and $1 \%$ level, respectively. T-statistics are in parentheses. The tables above present the results from the following regression:

$$
\operatorname{CAR}(-1,1)_{i t}=\beta_{1} T O N E_{i t}+\beta_{2} M A_{-} R_{i t}+\beta_{3} T O N E_{i t} * M A_{-} R_{i t}+\beta_{4} C A R(-60,-2)_{i t}+\beta_{5} S U R P_{i t}
$$
$+\beta_{6} R O A_{i t}+\beta_{7} S I Z E_{i t}+\beta_{8} M T B_{i t}+\beta_{9} V O L_{i t}+\Sigma I N D+\Sigma Y E A R+\Sigma Q U A R T E R+\varepsilon_{i t}$,

$\operatorname{CAR}(-1,1)$ is the cumulative abnormal return in the 3 -day window around the release of earnings announcements. $C A R(-60,-2)$ is

the cumulative abnormal return from 60 days to 2 days prior to the release of earnings announcements. TONE is measured as 100

multiplied by the difference between the positive word proportion and negative word proportion. $M A \_R$ is obtained at http://faculty.washington.edu/smcvay/abilitydata.html. SURP is measured as the difference between the actual EPS and the average of the mean analyst forecast. ROA is earnings before interest and taxes (EBIT) scaled by total assets. SIZE is calculated as the logarithm of (1+total assets), market-to-book ratio $(M T B)$ is the sum of market capitalization and long-term debt divided by total assets, and stock return volatility $(V O L)$ is the volatility of monthly stock returns in the past 12 months. 


\section{Additional analyses}

\subsection{Abnormal tone}

In this section, several additional analyses are presented. First, the two hypotheses are reexamined using abnormal tone instead of tone as the variable of interest. Following Huang et al. (2014), tone level is decomposed into two components. The normal component reflects a neutral tone that is commensurate with concurrent information about current firm quantitative performance; the residual component, i.e., the abnormal tone, is intended to capture the discretionary and inflated component of tone. Huang et al. (2014) argue that managers may manage the tone of earnings announcements so that they can bias investors' understanding of firm fundamentals. The stock market's positive reaction to abnormal tones in the 3-day window around the release of earnings announcements suggests that the market overreacts to abnormal tones (Huang et al., 2014; Arslan-Ayaydin et al., 2016). Previous studies calculate abnormal tone as the residual of a particular tone model that typically controls for CEO equity-based incentives $(W E A L T H)$ and firm fundamentals such as earnings $(R O A)$, size (SIZE), market-to-book ratio (MTB), and stock return volatility (VOL) (Huang et al., 2014; Arslan-Ayaydin et al., 2016; Davis and Tama-Sweet, 2012). In this study, abnormal tone (ABTONE) is derived from the residual in model (3):

$$
T O N E_{i t}=\gamma_{0}+\gamma_{1} W E A L T H_{i t}+\gamma_{2} R O A_{i t}+\gamma_{3} S I Z E_{i t}+\gamma_{4} M T B_{i t}+\gamma_{5} V O L_{i t}+\varepsilon_{i t}
$$

Table 2 shows that $A B T O N E$ has a mean of 0.028 and a median of 0.172 , suggesting that earnings announcements usually carry positive abnormal tones. Table 3 also shows that, as expected, $A B T O N E$ is largely correlated with $T O N E$, and is positively correlated with managerial ability $\left(M A \_R\right)$. Additionally, $A B T O N E$ is significantly correlated with earnings surprise $(S U R P)$ and abnormal market reactions around earnings announcement release dates $(C A R(-1,1))$. 
Fixed effects regressions are used to test both hypotheses using ABTONE; the results are reported in Table 6. Column (1) of Table 6 indicates that the portion of the abnormal tone that is not explained by firm fundamentals, CEO incentives, or industry, year, and quarter fixed effects is significantly positively associated with managerial ability at the $1 \%$ level, with a coefficient of 0.053. This result is in line with those reported in Table 4 and supports H1, which posits that more able managers tend to express a more positive tone in their earnings announcements. Column (2) of Table 6 reports qualitatively similar results to those in Table 5, supporting H2, which posits that market reactions to abnormal tone are strengthened by managerial ability, as evidenced by the coefficient of 0.011 and the t-value of 2.16 on the interaction between $A B T O N E$ and $M A \_R$. Collectively, the additional analyses based on abnormal tone provide further support for the main results. They provide empirical evidence that managerial ability is relevant in explaining the abnormal tone of earnings announcements and that the market has a stronger positive response to the abnormal tones of announcements made by stronger management teams. 
Table 6. OLS regressions using abnormal tones

\begin{tabular}{|c|c|c|}
\hline & $\begin{array}{c}(1) \\
A B T O N E\end{array}$ & $\begin{array}{c}(2) \\
C A R(-1,1)\end{array}$ \\
\hline ABTONE & & $\begin{array}{l}-0.004 \\
(-1.32)\end{array}$ \\
\hline$M A \_R$ & $\begin{array}{c}0.053 * * * \\
(4.08)\end{array}$ & $\begin{array}{l}0.003 \\
(1.20)\end{array}$ \\
\hline$A B T O N E * M A \_R$ & & $\begin{array}{c}0.011^{* *} \\
(2.16)\end{array}$ \\
\hline$C A R(-60,-2)$ & & $\begin{array}{l}0.003 \\
(0.80)\end{array}$ \\
\hline$S U R P$ & & $\begin{array}{c}0.065^{* * *} \\
(20.40)\end{array}$ \\
\hline$R O A$ & & $\begin{array}{l}-0.003 \\
(-0.27)\end{array}$ \\
\hline SIZE & & $\begin{array}{c}-0.002 * * * \\
(-3.54)\end{array}$ \\
\hline$M T B$ & & $\begin{array}{c}-0.004 * * \\
(-7.16)\end{array}$ \\
\hline$V O L$ & & $\begin{array}{l}-0.011 \\
(-0.67)\end{array}$ \\
\hline Industry Fixed Effect & Included & Included \\
\hline Year Fixed Effect & Included & Included \\
\hline Quarter Fixed Effect & Included & Included \\
\hline F-test: $\beta_{1}+\beta_{3}=0$ & & $\begin{array}{c}0.007 * * * \\
(2.58)\end{array}$ \\
\hline$R^{2}$ & 0.0870 & 0.0359 \\
\hline \#Obs. & 15,885 & 15,885 \\
\hline
\end{tabular}

$*$, **, and $* * *$ indicate significance at a $10 \%, 5 \%$, and $1 \%$ level, respectively. T-statistics are in parentheses.

The table above presents the results from the following regression:

$A B T O N E_{i t}=\alpha_{1} M A_{-} R_{i t}+\Sigma I N D+\Sigma Y E A R+\Sigma Q U A R T E R+\varepsilon_{i t}$

$C A R(-1,1)_{i t}=\beta_{1} A B T O N E_{i t}+\beta_{2} M A_{-} R_{i t}+\beta_{3} A B T O N E_{i t} * M A_{-} R_{i t}+\beta_{4} C A R(-60,-2)_{i t}+\beta_{5} S U R P_{i t}$

$+\beta_{6} R O A_{i t}+\beta_{7} S I Z E_{i t}+\beta_{8} M T B_{i t}+\beta_{10} V O L_{i t}+\Sigma I N D+\Sigma Y E A R+\Sigma Q U A R T E R+\varepsilon_{i t}$,

$A B T O N E$ is the abnormal tone calculated as the residual in the following OLS regression:

$T O N E_{i t}=\gamma_{0}+\gamma_{1} W E A L T H_{i t}+\gamma_{2} R O A_{i t}+\gamma_{3} S I Z E_{i t}+\gamma_{4} M T B_{i t}+\gamma_{5} V O L_{i t}+\varepsilon_{i t}$,

$C A R(-1,1)$ is the cumulative abnormal return in the 3-day window around the release of earnings announcements. $C A R(-60$,2 ) is the cumulative abnormal return from 60 days to 2 days prior to the release of the earnings announcements. TONE is measured as 100 multiplied by the difference between the positive word proportion and negative word proportion. $M A \_R$ is obtained at http://faculty.washington.edu/smcvay/abilitydata.html. WEALTH is the logarithm of the sum of three components: (1) aggregate value of shares owned by the CEO, (2) aggregate value of unexercisable options, and (3) aggregate value of unexercised exercisable options. SURP is measured as the difference between the actual EPS and the average of the mean analyst forecast. ROA is earnings before interest and taxes (EBIT) scaled by total assets. SIZE is calculated as the logarithm of (1+total assets), market-to-book ratio (MTB) is the sum of market capitalization and long-term debt divided by total assets, and stock return volatility $(V O L)$ is the volatility of monthly stock returns in the past 12 months. 


\subsection{Subsample analysis}

To further strengthen the argument that managerial ability affects market reactions to the tone of earnings announcements, the sample is partitioned into two subsamples by the median of the managerial ability score. Subsample 1 contains 7,944 observations with managerial ability scores that are smaller than or equal to the sample median of 0.005 . Subsample 2 contains 7,941 observations with larger-than-median managerial ability scores. The results of the regressions using the subsamples are reported in Table 7. In subsample 1, the 3-day cumulative abnormal return is not significantly associated with the tone of earnings announcements, whereas in subsample 2, the coefficient on tone is 0.006 , with a t-value of 2.63 . These results suggest that the stock market takes managerial ability into account when reacting to tone. In particular, when managerial ability is higher, the stock market appears to give higher credibility to the tone of earnings announcements, and therefore a more positive tone is associated with a higher cumulative abnormal return. However, when managerial ability is low, the tone of earnings announcements does not seem to be credible to the market and it has no significant association with cumulative abnormal return. This implication is consistent with $\mathrm{H} 2$, and with the implications of the results presented in Table 5. 
Table 7. OLS regressions of market reaction on high- and low-managerial ability subsamples

\begin{tabular}{|c|c|c|}
\hline & MA_SCORE $<=$ median & MA_SCORE $>$ median \\
\hline & $\begin{array}{c}(1) \\
C A R(-1,1)\end{array}$ & $\begin{array}{c}(2) \\
C A R(-1,1)\end{array}$ \\
\hline TONE & $\begin{array}{c}-0.0003 \\
(-0.15)\end{array}$ & $\begin{array}{c}0.006 * * * \\
(2.63)\end{array}$ \\
\hline$C A R(-60,-2)$ & $\begin{array}{l}0.005 \\
(0.94)\end{array}$ & $\begin{array}{l}0.0009 \\
(0.18)\end{array}$ \\
\hline$S U R P$ & $\begin{array}{c}0.062 * * * \\
(14.23)\end{array}$ & $\begin{array}{c}0.071 * * * \\
(14.64)\end{array}$ \\
\hline$R O A$ & $\begin{array}{l}-0.002 \\
(-0.11)\end{array}$ & $\begin{array}{l}-0.002 \\
(-0.11)\end{array}$ \\
\hline SIZE & $\begin{array}{c}-0.002 * * \\
(-2.34)\end{array}$ & $\begin{array}{c}-0.002 * * * \\
(-2.92)\end{array}$ \\
\hline$M T B$ & $\begin{array}{c}-0.004 * * * \\
(-3.81)\end{array}$ & $\begin{array}{c}-0.004 * * * \\
(-5.99)\end{array}$ \\
\hline$V O L$ & $\begin{array}{l}-0.013 \\
(-0.55)\end{array}$ & $\begin{array}{l}-0.010 \\
(-0.42)\end{array}$ \\
\hline Industry Fixed Effect & Included & Included \\
\hline Year Fixed Effect & Included & Included \\
\hline Quarter Fixed Effect & Included & Included \\
\hline$R^{2}$ & 0.0386 & 0.0404 \\
\hline$\# O b s$. & 7,944 & 7,941 \\
\hline
\end{tabular}

$*$, **, and $* * *$ indicate significance at a $10 \%, 5 \%$, and $1 \%$ level, respectively. T-statistics are in parentheses.

The table above presents the results from the following regression on two subsamples:

$C A R(-1,1)_{i t}=\beta_{1} A B T O N E_{i t}+\beta_{2} M A_{-} R_{i t}+\beta_{3} A B T O N E_{i t} * M A_{-} R_{i t}+\beta_{4} C A R(-60,-2)_{i t}+\beta_{5} S U R P_{i t}$ $+\beta_{6} R O A_{i t}+\beta_{7} S I Z E_{i t}+\beta_{8} M T B_{i t}+\beta_{10} V O L_{i t}+\Sigma I N D+\Sigma Y E A R+\Sigma Q U A R T E R+\varepsilon_{i t}$, $C A R(-1,1)$ is the cumulative abnormal return in the 3 -day window around the release of earnings announcements. $C A R(-60,-2)$ is the cumulative abnormal return from 60 days to 2 days prior to the release of earnings announcements. TONE is measured as 100 multiplied by the difference between the positive word proportion and negative word proportion. SURP is measured as the difference between the actual EPS and the average of mean analyst forecast. $R O A$ is earnings before interest and taxes (EBIT) scaled by total assets. SIZE is calculated as the logarithm of (1+total assets), market-to-book ratio (MTB) is the sum of market capitalization and long-term debt divided by total assets, and stock return volatility $(V O L)$ is the volatility of monthly stock returns in the past 12 months.

\section{Robustness Checks}

\subsection{Firm fixed effects}

As a robustness check to address the concern that the results might be driven by firmspecific characteristics, firm-specific effects are controlled for in the model. The results remain 
qualitatively consistent, although the significance level drops to $7.5 \%$ (one-tail). The drop in significance is probably because managerial ability is quite stable over the years. In particular, the sample contains 912 firms and 1,455 distinct firm-CEO pairs. This means that $63 \%$ of the firms have the same CEO throughout the sample period.

\subsection{Additional control variables for operational performance}

To further address the concern that earnings announcements tone may be driven by firm performance, two additional control variables are added to the model: operational loss and change in earnings per share. After controlling for these variables, managerial ability remains significantly associated with TONE, with a positive coefficient of 0.034 and a t-value of 2.48 . Among these two additional control variables, only LOSS is significantly and negatively associated with TONE, with a coefficient of -0.081 and a t-value of -6.28 . Changes in EPS is insignificant and negatively associated with tone.

\subsection{Moderating Effect of Corporate Governance}

It is important to identify the specific channel through which managerial ability affects the tone of earnings announcements, i.e., management private information or management optimism. If management optimism is the primary driver, then the positive association between $M A_{-} R$ and TONE should be weaker for firms with stronger governance (i.e., CEO does not play a dual role), as stronger governance constraints management optimism (e.g., Aguilera et al. 2017). Two empirical analyses are performed to test this association. First, equation (1) is re-estimated in subsamples of firms with different levels of corporate governance effectiveness, as proxied by DUALITY, which takes the value of 1 if the CEO is also the chairman of the board of directors, and 0 otherwise. If DUALITY equals 1 , the CEO may be more powerful in his/her firm, and this could mean that the tone of earnings announcements could be more biased (Baliga et al. 1996; Gul 
and Leung 2004). The untabulated results suggest that the coefficients of managerial ability in both subsamples are statistically significant at $5 \%$; the coefficient is 0.094 for the subsample where the CEO has a dual role and 0.074 for the subsample where the CEO does not have a dual role. This difference is statistically insignificant. In the second test, equation (1) is expanded by including DUALITY and its interaction with $M A \_R$ as additional control variables. The untabulated results suggest that $M A \_R$ has a coefficient of 0.097 and a t-value of 3.53, whereas DUALITY itself is statistically insignificant. DUALITY does not seem to affect managerial ability's impact on tone, as its interaction with $M A \_R$ is statistically insignificant with a coefficient of -0.020 and a t-value of -0.40 . To sum up, the results based on the subsample tests and interaction term analysis suggest there is no statistical difference in the strength of the association between $M A_{-} R$ and TONE for companies with different corporate governance effectiveness. This evidence rules out the management optimism channel, and leads to the conclusion that the main findings are primarily driven by the management private information channel.

\subsection{Change analysis}

This section further examines the effect of managerial ability on tone by investigating whether a change in managerial ability has an effect on tone. Specifically, according to Hypothesis 1, when the managerial ability score increases, the tone of earnings announcements should become more positive. To test this, this study calculates changes in fourth-quarter tone with respect to the same quarter of the previous year, and regresses the difference against changes in managerial ability relative to the previous year. The coefficient on change of MA rank is 0.105 , with a p-value of 0.055 . This suggests that as the managerial team becomes more able, the tone becomes more positive; this effect is statistically significant. 


\section{Conclusions}

Using the ranked managerial ability measure developed by Demerjian et al. (2012), this study examines the effect of managerial ability on the tone of earnings announcements and on the market response to the tone. The study finds that more able management teams use a more positive tone in their earnings announcements; this extends the list of known tone determinants documented in the literature, such as operational performance, managerial incentives, growth opportunities, and firm size. These results add to the understanding of the determinants of tone in earnings announcements and suggest that tone does not simply reflect a manager's private information about operational performance. Rather, the tone in earnings announcements is related to the management team's efficiency in converting corporate resources into revenue. Moreover, the results of this study suggest that stock markets have more pronounced positive reactions to positive tones in the earnings announcements issued by companies with more able management teams. In other words, investors put more weight on positive tones expressed by more able management teams. Thus, this study adds to the understanding of the market's reaction to earnings announcements. Overall, the study contributes to the understanding of both the determinants of and market reaction to the tone of earnings announcements and to the understanding of the effect of managerial ability on firms' financial reporting behavior.

Our findings have important implications for firms' management and boards of directors, market participants, and academic researchers. For firms' management and boards of directors, the findings suggest that they need to be aware of the tendency of more able management teams to use more positive tones and to take necessary actions to avoid over-optimistic earnings announcements. For market participants, the findings suggest that they should beware of overconfidence in the tone of earnings announcement issued by more able management teams. For 
academic researchers, the findings indicate that archival researchers need to take into account the determinants of the tone of earnings announcement; otherwise, this omitted, correlated variable could render their findings unreliable.

Future studies could empirically test some of these implications. For example, a study of the moderating effect of corporate governance on the association between managerial ability and tone would inform us about the effectiveness of boards or audit committees in constraining aggressiveness in the corporation's voluntary disclosure (e.g., earnings announcement and conference calls). Further, future research examining the impact of managerial ability on the conservatism and aggressiveness of GAAP accounting numbers in regulated, mandatory financial statements would further expand the understanding of its impact on financial reporting behavior. Lastly this study is subject to two caveats. First, due to the innate limitation of OLS regression, the findings mainly show the associations between managerial ability and tone of earnings announcements rather a causal relationship between these variables. Second, the sample only includes large companies, as the control for managerial incentives (WEALTH) is constructed from data drawn from the Execucomp database. Therefore, these findings may not be generalizable to small firms. 


\section{References}

Aguilera, R., K. Desender, M. Lamy, and J. Lee. (2017), "The governance impact of a changing investor landscape", Journal of International Business Studies, Vol. 48 No. 2, pp. 195-221.

Ahmed, A. S., and Duellman, S. (2013), "Managerial overconfidence and accounting conservatism", Journal of Accounting Research, Vol. 51 No. 1, pp. 1-30.

Arslan-Ayaydin, Ö., Boudt, K. and Thewissen, J. (2016), "Managers set the tone: Equity incentives and the tone of earnings press releases", Journal of Banking \& Finance, Vol. 72 (supplement), pp. s132-s147.

Baliga, B. R., Moyer, R. C., and Rao, R. S. (1996), "CEO duality and firm performance: What's the fuss?", Strategic Management Journal, Vol. 17 No. 1, pp. 41-53.

Bamber, L.S., Jiang, J. and Wang, I.Y. (2010), "What's my style? The influence of top managers on voluntary corporate financial disclosure", The Accounting Review, Vol. 85 No. 4, pp. 1131-1162.

Bertrand, M. and Schoar, A. (2003), "Managing with style: The effect of managers on firm policies", The Quarterly Journal of Economics, Vol. 118 No. 3, pp. 1169-1208.

Chen, Y., Wang, T., and Seng, J. (2015), "Voluntary accounting changes and post-earnings announcement drift", Asian Review of Accounting, Vol. 23 No. 1, pp. 2 - 16.

Davis, A.K., Ge, W., Matsumoto, D. and Zhang, J.L. (2015), "The effect of manager-specific optimism on the tone of earnings conference calls", Review of Accounting Studies, Vol. 20 No. 2, pp. 639-673.

Davis, A.K., Piger, J.M. and Sedor, L.M. (2012), "Beyond the numbers: Measuring the information content of earnings press release language", Contemporary Accounting Research, Vol. 29 No. 3, pp. 845-868.

Davis, A.K. and Tama-Sweet, I. (2012), "Managers' use of language across alternative disclosure outlets: Earnings press releases versus MD\&A", Contemporary Accounting Research, Vol. 29 No. 3, pp. 804-837.

Deloitte. (2015). "Current trends in audit committee reporting," Available at https://www2.deloitte.com/content/dam/Deloitte/us/Documents/audit/us-audit-currenttrends-audit-committee-reporting.pdf (accessed on December 7, 2016)

Demerjian, P., Lev, B. and McVay, S. (2012), "Quantifying managerial ability: A new measure and validity tests", Management Science, Vol. 58 No. 7, pp. 1229-1248.

Demerjian, P.R., Lev, B., Lewis, M.F. and McVay, S.E. (2013), "Managerial ability and earnings quality", The Accounting Review, Vol. 88 No. 2, pp. 463-498.

Demers, E.A. and Vega, C. (2014), "Understanding the role of managerial optimism and uncertainty in the price formation process: Evidence from the textual content of earnings announcements", working paper, University of Virginia, 24 March.

Doran, J.S., Peterson, D.R. and Price, S.M. (2012), "Earnings conference call content and stock price: the case of REITs", The Journal of Real Estate Finance and Economics, Vol. 45 No. 2, pp.402-434.

Dyreng, S., Hanlon, M. and Maydew, E. (2010), "The effects of executives on corporate tax avoidance", The Accounting Review, Vol. 85 No. 4, pp. 1163-1189.

Feldman, R., Govindaraj, S., Livnat, J. and Segal, B. (2010), "Management's tone change, post earnings announcement drift and accruals", Review of Accounting Studies, Vol. 15 No. 4, pp. 915-953. 
Frankel, R., Mayew, W.J. and Sun, Y. (2010), "Do pennies matter? Investor relations consequences of small negative earnings surprises", Review of Accounting Studies, Vol. 15 No. 1, pp. 220-242.

Jegadeesh, N. and Wu, D. (2013), "Word power: A new approach for content analysis", Journal of Financial Economics, Vol. 110 No. 3, pp. 712-729.

Garcia, D. (2013), "Sentiment during recessions", The Journal of Finance, Vol. 68 No. 3, pp. 1267-1300.

Ge, W., Matsumoto, D. and Zhang, J.L. (2011), "Do CFOs have style? An empirical investigation of the effect of individual CFOs on accounting practices", Contemporary Accounting Research, Vol. 28 No. 4, pp. 1141-1179.

Gordon, E., Henry, E., Peytcheva, M., and Sun, L. (2013), "Discretionary disclosure and the market reaction to restatements", Review of Quantitative Finance and Accounting, Vol. 41 No. 1, pp. 75-110.

Gul, F. A. (1983), "A note on the relationship between age, experience, cognitive styles and accountants' decision confidence", Accounting and Business Research, Vol. 14 No. 53, pp. $85-88$.

Gul, F. A., and Leung, S. (2004), "Board leadership, outside directors' expertise and voluntary corporate disclosures", Journal of Accounting and Public Policy, Vol. 23 No.5, pp.351379.

Hambrick, D.C. (2007),'Upper echelons theory: An update", Academy of Management Review, Vol. 32 No. 2, pp. 334-343.

Henry, E. (2008), “Are investors influenced by how earnings press releases are written?”, Journal of Business Communication, Vol. 45 No. 4, pp. 363-407.

Huang, X., Teoh, S.H. and Zhang, Y. (2014), "Tone management", The Accounting Review, Vol. 89 No. 3, pp. 1083-1113.

Jopson, B. (2007), "Enough already: Why corporate reporting so seldom enlightens", Financial Times, 10 April. Available at http://www.ft.com/cms/s/0/6f3ad052-e 700-11db-9034000b5df10621.html (accessed on July 14, 2016)

Krishnan, G.V. and Wang, C. (2015), "The relation between managerial ability and audit fees and going concern opinions", Auditing: A Journal of Practice \& Theory, Vol. 34 No. 3, pp. 139-160.

Liu, B. and McConnell, J.J. (2013), "The role of the media in corporate governance: Do the media influence managers' capital allocation decisions?”, Journal of Financial Economics, Vol. 110 No.1, pp. 1-17.

Loughran, T. and McDonald, B. (2011), "When is a liability not a liability? Textual analysis, dictionaries, and 10-Ks", The Journal of Finance, Vol. 66 No.1, pp. 35-65.

Loughran, T. and McDonald, B. (2014), "Measuring readability in financial disclosures", The Journal of Finance, Vol. 69 No. 4, pp. 1643-1671.

Pinello, A.S. (2008), 'Investors' differential reaction to positive versus negative earnings surprises", Contemporary Accounting Research, Vol. 25 No. 3, pp. 891-920.

Price, S.M., Doran, J.S., Peterson, D.R. and Bliss, B.A. (2012), "Earnings conference calls and stock returns: The incremental informativeness of textual tone", Journal of Banking \& Finance, Vol. 36 No. 4, pp. 992-1011.

Rogers, J.L., Van Buskirk, A. and Zechman, S.L. (2011), "Disclosure tone and shareholder litigation", The Accounting Review, Vol. 86 No. 6, pp. 2155-2183. 
Twedt, B. and Rees, L. (2012), "Reading between the lines: An empirical examination of qualitative attributes of financial analysts' reports", Journal of Accounting and Public Policy, Vol. 31 No.1, pp. 1-21.

Yang, H.I. (2012), "Capital market consequences of managers' voluntary disclosure styles", Journal of Accounting and Economics, Vol. 53 No.1, pp. 167-184. 


\section{Appendix}

\begin{tabular}{|c|c|c|}
\hline Variable & Description & Definition \\
\hline TONE & Tone of earnings announcements & $100 *$ (Positive word count - Negative word count)/Total word count \\
\hline$A B T O N E$ & Abnormal tone & Residual from model (3): \\
\hline & & $T O N E_{i t}=\gamma_{0}+\gamma_{1} L O G W_{i t}+\gamma_{2} R O A_{i t}+\gamma_{3} S I Z E_{i t}+\gamma_{4} M T B_{i t}+\gamma_{5} V O L_{i t}+\varepsilon_{i t}$ \\
\hline$M A \_R$ & Decile rank of managerial ability score & Downloaded from http://faculty.washington.edu/smcvay/abilitydata.html \\
\hline WEALTH & Logarithm of CEO equity-based wealth & $\begin{array}{l}\text { Logarithm of the aggregate dollar amount of CEO's firm-specific equity-based } \\
\text { wealth, which includes total value of shares owned by the CEO, value of } \\
\text { unexercisable options (opt_unex_unexer_est_val in ExecuComp), and value of } \\
\text { unexercised exercisable options (opt_unex_exer_est_val in ExecuComp) }\end{array}$ \\
\hline$R O A$ & Return on assets & Earnings before interest and taxes/Total assets \\
\hline SIZE & Firm size & Logarithm of total assets \\
\hline$M T B$ & Market-to-book ratio & (Market capitalization + Long-term debt)/Total assets \\
\hline$V O L$ & Stock return volatility & Volatility of monthly stock returns in the past 12 months \\
\hline SURP & Earnings surprise & Actual EPS - Mean of analyst forecast \\
\hline$C A R(-1,1)$ & Cumulative abnormal return & $\begin{array}{l}\text { Cumulative abnormal return for the }(-1,1) \text { window, with day } 0 \text { being the earnings } \\
\text { announcement day }\end{array}$ \\
\hline$C A R(-60,-2)$ & Cumulative abnormal return & $\begin{array}{l}\text { Cumulative abnormal return for the }(-60,-2) \text { window, with day } 0 \text { being the earnings } \\
\text { announcement day }\end{array}$ \\
\hline
\end{tabular}


Endnotes:

${ }^{1}$ Empirical analyses are performed to identify which of the two potential channels, management private information or management optimism, drives the results of the positive association between managerial ability and the tone of earnings announcements. The empirical evidence drawn from the subsample tests and interaction terms reveals no statistical difference in the strength of the association between managerial ability and tone of earnings announcement, which rules out managerial opportunism as a significant channel and supports the argument that management private information is the main channel of the effect of managerial ability on the tone of earnings announcements.

${ }^{2}$ Specifically, Demerjian et al. (2013) find evidence that managerial ability improves earnings quality by showing that more able management teams are associated with fewer subsequent restatements, higher earnings and accrual persistence, and higher quality accrual estimations. Krishnan and Wang (2015) suggest that managerial ability is informative to auditors in lowering audit risk and improving auditors' reporting decisions.

${ }^{3}$ This paragraph relies heavily on Krishnan and Wang $(2015$, p. 142).

${ }^{4}$ Please refer to Demerjian et al. $(2012,2013)$ and Krishnann and Wang (2015) for a discussion of how the managerial ability score is calculated. The managerial ability rankings used in this study are downloaded from http://faculty.washington.edu/smcvay/abilitydata.html.

${ }^{5}$ Additional analysis is performed by regressing the decile rank of TONE against the decile rank of $M A \_R$; the coefficient of $M A_{-} R$ is 0.47 . This suggests that as $M A_{-} R$ increases by one decile rank, TONE increases by 0.47 decile rank. Moreover, the analysis using the standardized coefficient suggests that $M A \_R$ is the second most important explanatory variable for Tone, following ROA.MA_R is more important than CEO-equity based wealth, firm size, and growth. 